\title{
Effect of Rearing Systems on Reproductive Performance of Turkey
}

\author{
M Anna Anandh*, P N Richard Jagatheesan, P Senthil Kumar, A Paramasivam, G Rajarajan \\ Tamil Nadu Veterinary and Animal Sciences University \\ Regional Research Centre, Pudukkottai - 622 004, Tamil Nadu, India. \\ * Corresponding author email: drmaatnvasu@yahoo.com \\ Received: 16-09-2011, Accepted: 21-10-2011, Published Online: 20-12-2011 \\ doi: $10.5455 /$ vetworld.2012.226-229
}

\begin{abstract}
The objective of this study was to determine the effect of rearing systems on reproductive performance of turkey (Meleagris gallopavo). A total of 180 Beltsville Small White and Board Breasted Bronze turkeys were taken for the study and reared under three different rearing system viz. intensive system (full confinement), semi-intensive system (partial confinement and partial day scavenging) and free range system (all-day scavenging). Average egg weight (g), percentage of infertile eggs, embryonic mortalities, total egg hatchability, fertile egg hatchability, fertility and poults survivability values were significantly $(\mathrm{P}>0.01)$ higher in turkeys reared under intensive system of management followed by semi intensive system and free range system of management. The highest percentage of dead in shell was found in intensive system and was did not differ significantly from semi intensive and free range system. Hatched weight of poults ( $\mathrm{g}$ ) between semi intensive and intensive system did not differ significantly between them, but both groups found statistically significant $(P>0.01)$ from free range system. From the study, it is concluded that higher reproductive performance was obtained in intensive system of management followed by semi intensive and free range system of management.
\end{abstract}

Keywords: Turkey, Poults, Egg, Reproductive traits, Hatching, Fertility, Hatchability, Survivability

To cite this article : AnnaAnandh M, Richardj agatheesan P N, Senthil Kumar P, Paramasivam A, Rajarajan G (2012) Effect of Rearing Systems on Reproductive Performance of Turkey, Vet. World. 5(4):226-229, doi: 10.5455/vetworld.2012.226-229.

\section{Introduction}

The turkey (Meleagris gallopavo) a well known bird in western countries, but in the rest of the world especially in developing countries it is yet to be established on commercial point of view. Commercial turkey farming is becoming popular in India and farmers started to show interest in rearing turkey birds. The bird is quite suitable for upliftment of small and marginal farmers as it can be easily reared with little investment for housing, equipment and management. One of the main objectives in turkey breeder production is to increase the number of poults produced. Egg yields in turkeys are lower than that of other poultry species. In addition to low egg yield, unsatisfactory egg fertility and hatchability constitute a major problem for turkey breeding enterprises (Ozcelik et al., 2009). Egg weight, fertility and embryonic mortality would influence overall hatching performance provided management conditions are not the limiting factors. Egg weight, fertility, hatchability and late embryonic mortality varied greatly between traditional and modern breeding management system (Lariviere et al., 2009). Variations in fertility, hatchability, embryonic mortalities and survivability may be due to poor egg holding period, imbalanced nutrition, stressful conditions the parent flock was exposed to rearing condition. Low fertility and high embryonic mortality values have been reported in traditional chicken rearing (Hocking et al., 2007). This can be explained by poor management practices, mating behavior or reproductive physiology in flocks often maintained in small groups.

Since scanty published literature is available on hatching performance of turkey birds under different rearing systems in India, the present study was conducted to determine the effects of rearing system on the reproductive performance of turkeys as well as to identify the suitable rearing system for rearing turkeys.

\section{Materials and Methods}

Experimental design and management: The study was conducted at Turkey Research Unit of TamilNadu Veterinary and Animal Sciences University - Regional Research Centre, Pudukkottai, Tamil Nadu, India during the year 2010 - 11. Beltsville Small White and Broad Breasted Bronze turkeys at an age of 28 weeks, 180 breeders were assigned to the three treatments in a completely randomized design with 
Effect of Rearing Systems on Reproductive Performance of Turkey

Table-1. Effect of rearing system reproductive traits of turkeys ( Mean \pm SE)

\begin{tabular}{|c|c|c|c|}
\hline Reproductive traits & Free range system & Semi intensive system & Intensive system \\
\hline Egg weight(gm) & $68.72 \pm 0.15^{\mathrm{a}}$ & $70.56 \pm 0.13^{b}$ & $72.70 \pm 0.18^{c}$ \\
\hline Infertile eggs (\%) & $31.14 \pm 0.13^{\mathrm{a}}$ & $29.37 \pm 0.15^{b}$ & $9.04 \pm 0.16^{c}$ \\
\hline Late embryonic mortality (\%) & $6.57 \pm 0.07^{\mathrm{a}}$ & $4.91 \pm 0.13^{b}$ & $3.36 \pm 0.15^{c}$ \\
\hline Dead in shell (\%) & $7.30 \pm 0.11^{\mathrm{NS}}$ & $7.59 \pm 0.12^{N s}$ & $7.62 \pm 0.11^{\mathrm{NS}}$ \\
\hline Total egg hatchability (\%) & $52.85 \pm 0.13^{\mathrm{a}}$ & $56.84 \pm 0.19^{b}$ & $77.38 \pm 0.11^{c}$ \\
\hline Poults hatched weight (gm) & $42.08 \pm 0.17^{\mathrm{a}}$ & $47.18 \pm 0.15^{b}$ & $47.82 \pm 0.12^{b}$ \\
\hline Survivability (\%) & $69.61 \pm 0.16^{\mathrm{a}}$ & $81.71 \pm 0.16^{b}$ & $92.06 \pm 0.14^{c}$ \\
\hline
\end{tabular}

$* \mathrm{P}<0.01$; NS-non significant. Means bearing same superscripts row-wise do not differ significantly.

two replicates, for an experimental period of 20 weeks. The birds under treatment group I were reared in intensive system (full confinement), birds under treatment group II were reared in semi-intensive system (partial confinement and partial day scavenging) and birds under treatment group III were reared under free range system (all-day scavenging) of management and the birds maintained under standard management practices. Each group was housed in separate experimental houses whose floors were raised and covered with sawdust litter. Free mating was allowed in the flock and the sex ratio was 1:4.

Feed containing $15.5 \%$ crude protein and 2750 $\mathrm{kcal} / \mathrm{kg}$ energy was fed ad libitum to the birds reared under intensive and semi intensive system of management and in free range system $100 \mathrm{~g} /$ day of a concentrate feed provided. Fresh water was made available to the birds throughout the day. The eggs were collected, randomly selected, weighed. The collected eggs were stored at room temperature for about 3-5 days and then used for incubation. Proper cleaning, disinfection and fumigation were conducted before setting of eggs. The temperature of $99.5^{\circ} \mathrm{F}$ in dry bulb and relative humidity of $87.0^{\circ} \mathrm{F}$ in wet bulb were set to incubate the eggs for 25 days during which they were rotated hourly interval.

Thereafter, these eggs were transferred to the hatcher where temperature $98.5^{\circ} \mathrm{F}$ in dry bulb and relative humidity of $90.0^{\circ} \mathrm{F}$ in wet bulb were maintained. Hatching started on the day 27 and was completed by the end of the $28^{\text {th }}$ day. The process used, fumigation, storage conditions, machine conditions were uniform for all experimental groups.

Reproductive performance: At the end of hatching process, egg were classified as infertile, hatched, embryonic mortalities (early and late) and dead in shell. Hatched poults were collected, counted and weighed by using an electronic balance. Reproductive performances were calculated and included total egg hatchability (poults hatched / total eggs set x 100), fertile egg hatchability (poults hatched / fertile eggs set $x$ 100) and fertility (total eggs set - infertile eggs / total eggs set $x$ 100) of each rearing systems were calculated.

Statistical analysis: The data generated from each experimental group were analyzed statistically by following standard procedures (Snedecor and Cochran, 1989) for comparing the means and to determine the effect of rearing systems.

\section{Results and Discussion}

Effect of rearing system on egg weight, percentage of infertile eggs, embryonic mortalities, dead in shell, total egg hatchability, fertile egg hatchability, fertility, poults hatched weight and poults survivability of turkey are presented in Table 1.The mean \pm SE average egg weight in the free range, semi intensive and intensive system were found to be 68.72 $\pm 0.15,70.56 \pm 0.13$ and $72.70 \pm 0.18$, respectively. The average egg weight between each rearing system differ significantly $(\mathrm{P}>0.01)$ between them. The highest average egg weight was found in intensive system of management followed by semi intensive and free range system. Ramlah (1996) also reported increased egg weight in hens reared under intensive system of management as compared to semi intensive system of management.

The mean egg weight obtained in the present study is in accordance with the findings of Ozcelik et $a l$., (2009) who reported the mean weight of turkey eggs ranged 67.4 to $70.3 \mathrm{~g}$. The mean $\pm \mathrm{SE}$ percentage of infertile eggs in the free range, semi intensive and intensive system were found to be $31.14 \pm 0.13$, $29.37 \pm 0.15$ and $9.04 \pm 0.16$ respectively. The mean percentage of infertile eggs were differ significantly $(\mathrm{P}>0.01)$. The highest infertile eggs were found in turkeys reared in free range system followed by semi 
intensive system and intensive system of management. Mroz et al., (2010) reported that the number of infertile eggs is low in turkeys, but it may reach $10 \%$ at the beginning and towards the end of the laying season. The mean \pm SE percentages of early and late embryonic mortalities in the free range, semi intensive and intensive system were found to be $6.63 \pm 0.07$ and $6.57 \pm 0.07,5.69 \pm 0.10$ and $4.91 \pm 0.13$ and $3.76 \pm 0.08$ and $3.36 \pm 0.15$, respectively. Early and late embryonic mortalities percentage of all treatment groups differ significantly $(\mathrm{P}>0.01)$ between them.

Lowest percentages of embryonic mortalities were found in turkeys reared under the intensive system of management. The highest percentages of embryonic mortalities were found in free range system followed by semi intensive system of management. Hocking et al., (2007) also reported that high embryonic mortality values in traditional chicken rearing. The mean \pm SE percentage of dead in shell in the free range, semi intensive and intensive system were found to be $7.30 \pm 0.11,7.59 \pm 0.12$ and $7.62 \pm 0.11$, respectively. The highest percentage of dead in shell was found in intensive system and was did not differ significantly from semi intensive and free range system. Increased dead in shell in the intensive system of management is due due to increasing egg size, that larger eggs would be expected to have greater difficulty initially achieving adequate embryonic temperature and then losing embryonic metabolic heat dissipation in large eggs has been found to result in higher embryo temperature in large eggs as compared to light eggs as obtained free range system of management (Altan et al., 1995).

The mean \pm SE percentage of total egg hatchability, fertile egg hatchability and fertility in the free range, semi intensive and intensive system were found to be $52.85 \pm 0.13,79.12 \pm 0.12$ and $68.85 \pm 0.13$, $56.84 \pm 0.19,81.34 \pm 0.15$ and $70.55 \pm 0.17$ and $77.38 \pm 0.11,84.79 \pm 0.15$ and $90.95 \pm 0.16$ respectively. The highest total egg hatchability percentage, fertile egg hatchability and fertility were found in the intensive system followed by semi intensive and free range system and the values differ significantly $(\mathrm{P}>0.01)$ between each rearing system. Optimum hatching results can be obtained from heavy eggs as obtained in intensive and semi intensive system of rearing. It has been reported that hatchability of turkey eggs is maximized with eggs weighing between 70 $85.5 \mathrm{~g}$ (Karacanta et al., 1977). The effect of egg size on hatchability was explained by Deeming (1997) who stated that the effect of egg size on hatchability was due to a reduction in the surface area to volume ratio with increasing egg size making the gas heat exchange more difficult. Low fertility values have also been reported in traditional chicken rearing (Hocking etal., 2007).

This can be explained by poor management practices, mating behavior or reproductive physiology in flocks often maintained in small groups. A number of factors including storage condition system of husbandry and rearing technology, mating system have been shown to influence the hatchability of poultry eggs (Brah and Sandhu,1989, GebhardtHenrich and Marks, 1991). The present findings were also in conformity with above findings. The mean \pm SE percentage of turkey poults hatched weight in the free range, semi intensive and intensive system were found to be $42.08 \pm 0.17,47.18 \pm 0.15$ and $47.82 \pm 0.12$, $47.51 \pm 0.13$, respectively.

The percentage of hatched weight of poults was found higher in intensive system followed by semi intensive system and free range system. The difference between poult hatched weight in semi intensive and intensive system did not differ significantly between them, but both groups found statistically significant $(\mathrm{P}>0.01)$ from free range system. Shanaway (1987) reported hatching weight constitutes $63.5 \%$ of egg weight in turkey egg. The present results also in conformity with above results. The mean \pm SE of survivability of turkey poults in the free range, semi intensive and intensive system were found $69.61 \pm 0.16,81.71 \pm 0.16$ and $92.06 \pm 0.14$, respectively. Turkey poults survivability of intensive system being significantly higher followed by semi intensive system and free range system. This may be due to good management practices and feeding of poults under intensive system of management. It is well documented that mortality is influenced by several factors such as exposition to cold weather during the first three weeks, heat stress in the end of the growing period, problems in water distribution, as well as inappropriate housing and bird density. Severe rearing losses, with high mortality in young indigenous chickens have been reported under traditional management systems (Wilson, 1986).

\section{Conclusion}

From these results, it is concluded that, rearing system had a very significant effect on hatching performance of turkeys. Turkeys reared under intensive system of management suitable for to obtain better reproductive performance followed by semi intensive and free range system of management. 


\section{Acknowledgements}

The authors thanks the Director, Centre for Animal Production Studies, Tamil Nadu Veterinary and Animal Sciences Univesity, Chennai-51, Tamil Nadu, India for providing necessary facilities and permission under self financing scheme on "The development of modern technology in turkey rearing and popularization of the same among the rural people in Pudukkottai district”.

\section{Conflict of interest}

Authors declare that they have no conflict of interest.

\section{References}

1. Altan, O., Oguz, I. and Settar, P. (1995). Effect of egg weight and specific gravity of the hatchability characteristics in Japanese quail. Turk. J. Agric. For., 19, 219-222.

2. Brah, G. S. and Sandhu, J. S. (1989). Pre incubation storage of guinea fowl eggs in cooling cabinet vs. room: Effect on hatchability components. Tropical Agri., 66:265-268.

3. Gebhardt-Henrich, S.G. and Mark, H. L. (1991). The effect of switching males among caged females on egg production and hatchability in Japanese quail. Poult. Sci., 70:1845-1847.

4. Hocking, P.M., Robertson, G.W. and Teverson, D.
(2007). Fertility and early embrionic mortality in traditional breeds of chicken in the UK. In. Proc. 5th European Poultry Genetic Symposium, Braedstrup, Denmark, Pp.108.

5. Karacanta, A., Aybey, M., Kocak, C. and Gonul, T. (1977). Effect of egg weight on hatchability in parent Bronze turkey. J.Agri. Fac. Ege Uni., 13:133137.

6. Lariviere,J-M., Michaux, C., Famir, F., Detilleux, J., Verleyen, V. and Leroy, P. (2009). Peproductive performance of the ardennaise chicken breed under traditional and morden breeding management system. Int.J. Poult. Sci., 8:446-451.

7. Mroz, E., Orlowska, A and Stepinska, M. (2010). Hatchery waste and Hatchability of turkey eggs. Pol. J. Natur. Sci., 25: 143-153.

8. Ozcelik, M., Ekmen, F. and Elmaz, O. (2009). Effect of location of eggs in the incubator on hatchability of eggs from Bronze turkey breeders of different ages. South African JAni. Sci.. 39: 214- 222.

9. Ramlah, A.H. (1996). Performance of village chickens in Malaysia. World Poult. Sci.J., 52: 75-79.

10. Shanawany, M. M. (1987). Hatching weight in relation to egg weight in domestic birds. World's Poult.Sci. J., 43: 107-115.

11. Snedecor, G.W. and Cochran, W.G. (1989). Statistical methods. 8 th ed. Oxford and IBH Publishing Co., Calcutta.

12. Wilson, R. T. (1986). Poultry production in Sub Sahara Africa. Outlook on Agri.,15: 121-127. 